\title{
Storage and use of residual newborn screening blood spots: A public policy emergency
}

\author{
Beth A. Tarini, MD, MS
}

$T^{\text {h }}$ he Secretary of Health and Human Services' Advisory Committee on Heritable Disorders in Newborns and Children (SACHDNC) is a federally appointed committee whose responsibility is "to advise the Secretary regarding the most appropriate application of universal newborn screening tests, technologies, policies, guidelines and standards for effectively reducing morbidity and mortality in newborns and children having, or at risk for, heritable disorders." ${ }^{1}$ In this issue of Genetics in Medicine, SACHDNC has set forth recommendations that provide national guidance on state policies regarding the storage and use of residual dried blood spots (DBS) after newborn screening (NBS). ${ }^{2}$ They have based their recommendations on over a year of investigation and deliberation (started in February 2009) involving international and national experts in NBS, public health and law, and members of the lay public. Although they should be commended for their efforts in bringing this contentious discussion onto the national stage, it comes too late for some states.

Those not familiar with the issue of residual NBS blood spots might ask-Why does SACHDNC feel compelled to set forth recommendations now? In some states, DBS have been stored and used for decades ${ }^{3}$ for quality improvement purposes (e.g., calibration of equipment) and for epidemiologic and environmental studies unrelated to NBS. ${ }^{4-6}$ In addition, a federally funded consortium of regional genetic services networks previously published guidelines on the use and storage of these residual blood spots in $1996 .^{7}$

Two factors loom large in these recommendations: genetic technology and lawsuits filed against states in 2009. With the completion of the human genome project and the popularity of genome-wide association studies, the research value of residual DBS has skyrocketed. In fact, this year, researchers successfully amplified DNA and conducted genome-wide gene expression profiles using DBS. ${ }^{8}$ Researchers have also successfully extracted and amplified RNA from stored unfrozen samples almost a decade old. ${ }^{9}$

Although SACHDNC hints gently at the lawsuits with their reference to "heightened public awareness" and "concerns in some consumer communities regarding both the potential uses of residual specimens and patient (newborn and family) privacy," this language does not do full justice to the acrimonious nature of the disputes. The first lawsuit came from families in Minnesota who alleged that storage and use of DBS violated the state's Genetic Privacy Act. ${ }^{9}$ The court dismissed the case, ruling that the state's Genetic Privacy Act was not applicable to the NBS program. In a subsequent appeal, the Minnesota Court

From the Department of Pediatrics, Child Health Evaluation and Research (CHEAR) Unit, Ann Arbor, Michigan.

Beth A. Tarini, MD, MS, Department of Pediatrics, Child Health Evaluation and Research (CHEAR) Unit, University of Michigan, 300 N. Ingalls Street, Room 6C11, Ann Arbor, MI 48109-5456. E-mail: btarini@umich.edu.

Disclosure: The author declares no conflict of interest.

Published online ahead of print June 13, 2011

DOI: 10.1097/GIM.0b013e31822176df of Appeals affirmed the original court's ruling, ${ }^{11}$ and the case is going to the Minnesota Supreme Court. The second lawsuit was filed against the Texas State Department of Health by families who claimed storage and use of NBS for undisclosed research purposes violated their constitutional protection from unlawful search and seizure. ${ }^{12}$ This case was settled. However, the terms of the settlement required the state to destroy more than 5 million residual DBS - a move that stunned many in the NBS community. ${ }^{13,14}$

It is neither surprising nor unreasonable that members of the public have voiced concerns about appropriate privacy safeguards and DBS. What is surprising is the bitter and contentious atmosphere surrounding these lawsuits, much of it stemming from antigovernment rhetoric that brands storage and use of DBS as "Big Brother in one of its worst incarnations" 15 and accuses the government of building a DNA biobank for eugenic purposes. ${ }^{16}$ Unfortunately, the rhetoric has only escalated amid the recent national debate about healthcare reform with claims that the government will ultimately use DBS to ration healthcare. ${ }^{16}$ These claims are unfounded and, in some cases, represent a coopting of these issues for broader political agendas. It has not helped that the state of Texas is currently embroiled in a lawsuit over failure to disclose that it provided 800 anonymous DBS specimens to the US Armed Forces Laboratory to assist creation of a forensics database. ${ }^{17}$ The reality is that these specimens were used to determine population-level variation in DNA among different ethnic groups. Unfortunately, perception often trumps reality, and this incident has fueled public mistrust of NBS and DBS beyond the boundaries of the state of Texas.

Clearly, much of the publicized backlash is not simply about protection of privacy but rather protection of privacy from perceived government intrusion. This is hardly surprising given that polls last year revealed public trust in government was at its lowest in 45 years, while anger and frustration at the government was at its highest in the past decade. ${ }^{18}$ So although SACHDNC is correct that with the storage and use of DBS the "privacy and confidentiality (of individuals) should be ensured," the challenge for state public health departments that run NBS programs is that they must do so in a politically charged antigovernment climate.

This is not to say that scientific policy should be ruled by the politics of the day or bend at the will of a few, loud voices. Research suggests that most parents support research with these newborn screening samples. ${ }^{19,20}$ The goal should not be to persuade the minority that opposes such research: It is unlikely that even the best of efforts by public health officials will change the opinion of those who strongly oppose the storage and use of DBS. Rather, the goal should be to address their concerns in a respectful and meaningful way, so as to prevent the spread of fear and misinformation to the majority. In pediatrics, we have witnessed a similar phenomenon with vaccine refusal that provides valuable lessons. ${ }^{21}$

In short, the challenge for state NBS programs is not just to develop explicit and transparent policies regarding the storage and use of NBS DBS - although that is a necessary first step. The real challenge lies in getting the public to believe in these 
processes and the value of the DBS. SACHDNC does acknowledge the problem of "an unclear message to the public about the purpose of storage and use of residual NBS blood specimens."2 Although they highlight the value of the DBS throughout the recommendations - describing them as "valuable resources for the public good" and asking policymakers to "consider the value of the specimens as a promising resource for research"specific examples in which DBS specimens have generated important public health and medical insights ${ }^{4}$ are not provided. Although the value of the DBS specimens may be a foregone conclusion to those of us who work in public health and scientific research, that is unlikely to be the case for the general public. Given that the collections of DBS are a public resource provided by the public, it is our responsibility to showcase existing studies to explicitly demonstrate research using DBS is valuable and provides an important public good.

To some extent, this controversy is emblematic of a larger problem of public awareness about NBS, which SACHDNC also acknowledges in its report. Much of the public has little understanding or awareness of the NBS program, which identifies individual newborns with inherited conditions, so that they may receive early, effective treatment. ${ }^{22}$ SACHDNC recognizes the danger that the public may conflate the clinical NBS program with the storage and use of residual NBS blood spots for research-"minimal public awareness of NBS ... has engendered public concern about the storage of residual NBS specimens even for standard NBS program uses." In fact, it has already happened. Privacy advocates have gone on record referring to NBS as "The New Eugenics"23 — a preposterous claim that may encourage some parents to refuse this potentially lifesaving testing for their newborns. It is critical that all educational efforts ensure that the NBS program and storage and use of residual DBS for research of DBS are distinct in the public's mind.

The response to these threats to NBS and DBS should not be to "tighten the screw" on public engagement about the use and storage of residual DBS. On the contrary, states should allow parents a choice in whether their child's blood spot is used for research that is not directly related to quality improvements of the existing tests with NBS programs. Research suggests that denying parents an opportunity to provide their permissionwhether through opt-in or opt-out mechanisms, written or verbal-is likely to damage public support ${ }^{20}$ causing programs to lose both the battle and the war. Michigan provides an example of a state that has successfully embarked on a consent program for storage of both past and future DBS. ${ }^{24}$

Discussions about the storage and use of DBS have focused heavily on legal (e.g., who owns the DBS) and ethical research issues. For example, SACHDNC explicitly notes that "there are no documented cases of harm resulting from the use of residual NBS specimens." However, this misses the point. The real challenge with the storage and use of residual NBS is neither an ethical nor a legal one-it is a public policy one. These samples were taken as part of a mandatory public health screening program. Failure to allow parents a voice in whether those samples are used for other purposes fuels the antigovernment ire. Some worry that establishing consent/dissent processes for storage and use of DBS will hamper enrollment. Paradoxically, it is likely that allowing parents the opportunity to say "no" may actually get them to say "yes." Those not convinced should ask Andrea Beleno, one of the plaintiffs, in the Texas lawsuit, who said "And if they'd asked me if I would consent for this blood to be used for specific medical research . . . I would have probably said yes." 15

\section{ACKNOWLEDGMENTS}

This work was supported by a K23 Mentored Patient-Oriented Research Career Development Award from the Eunice Kennedy Shriver National Institute of Child Health and Human Development (NICHD) (K23HD057994, B.A.T.).

\section{REFERENCES}

1. Health Resources and Services Administration. Secretary's Advisory Committee on Heritable Disorders in Newborns and Children, 2011. Available at: http://www.hrsa.gov/heritabledisorderscommittee/. Accessed April 22, 2011.

2. Therrel BL Jr, Hannon WH, Bailey DB Jr, Goldman EB, Monaco J, NorgaardPedersen B, et al. Committee report: considerations and recommendations for national guidance regarding the retention and use of residual dried blood spot specimens after newborn screening. Genet Med 2011;13:621-624.

3. Olney RS, Moore CA, Ojodu JA, Lindegren ML, Hannon WH. Storage and use of residual dried blood spots from state newborn screening programs. $J$ Pediatr 2006;148:618-622.

4. Parker SP, Cubitt WD. The use of the dried blood spot sample in epidemiological studies. J Clin Pathol 1999;52:633-639.

5. Spliethoff HM, Tao L, Shaver SM, et al. Use of newborn screening program blood spots for exposure assessment: declining levels of perluorinated compounds in New York State infants. Environ Sci Technol 2008;42:5361-5367.

6. Choi KY, Schimmenti LA, Jurek AM, et al. Detection of cytomegalovirus DNA in dried blood spots of Minnesota infants who do not pass newborn hearing screening. Pediatr Infect Dis $J$ 2009;28:1095-1098.

7. Therrell BL, Hannon WH, Pass KA, et al. Guidelines for the retention, storage, and use of residual dried blood spot samples after newborn screening analysis: statement of the Council of Regional Networks for Genetic Services. Biochem Mol Med 1996;57:116-124.

8. Khoo SK, Dykema K, Vadlapatla NM, et al. Acquiring genome-wide gene expression profiles in Guthrie card blood spots using microarrays. Pathol Int 2011;61:1-6.

9. Haak PT, Busik JV, Kort EJ, Tikhonenko M, Paneth N, Resau JH. Archived unfrozen neonatal blood spots are amenable to quantitative gene expression analysis. Neonatology 2009;95:210-216.

10. Bearder et al. v State of Minnesota et al. Fourth Judicial Circuit Court; November 24, 2009. Order granting motion to dismiss court file 27-CV-095615.

11. Bearder et al. v State of Minnesota et al. Minnesota Court of Appeals; August 24, 2010. Affirmation of Fourth Judicial Circuit Court court file 27-CV-09-5615.

12. Beleno v Texas Dept. of State Health Serv. Case 5:2009cv00188. U.S. District Court for the Western District of Texas in San Antonio, March 3, 2009.

13. Grody WW, Howell RR. The fate of newborn screening blood spots. Pediatr Res 2010;67:237

14. Waldo A. The Texas newborn bloodspot saga has reached a sad — and preventable_conclusion. Genomics Law Report ${ }^{\circledR}, 2010$. Available at: http://www. genomicslawreport.com/index.php/2010/03/16/the-texas-newborn-bloodspotsaga-has-reached-a-sad-and-preventable-conclusion/. Accessed April 22, 2011.

15. Roser MA. State sued over babies' blood. Austin American-Statesman, March 13, 2009.

16. Citizens' Council for Health Freedom, 2011. Available at: http://www. cchfreedom.org/. Accessed April 22, 2011.

17. Ramshaw E. DSHS turned over hundreds of DNA samples to feds. The Texas Tribune, February 22, 2010.

18. The Pew Research Center. Distrust, discontent, anger and partisan rancor. The People and Their Government, April 18, 2010. Available at: http:// people-press.org/files/legacy-pdf/606.pdf. Accessed on April 22, 2011.

19. Duquette D, Rafferty AP, Fussman C, Gehring J, Meyer S, Bach J. Public support for the use of newborn screening dried blood spots in health research. Public Health Genomics 2011;14:143-152.

20. Tarini BA, Goldenberg A, Singer D, Clark SJ, Butchart A, Davis MM. Not without my permission: parents' willingness to permit use of newborn screening samples for research. Public Health Genomics 2010;13:125-130.

21. Poland GA, Jacobson RM. Understanding those who do not understand: a brief review of the anti-vaccine movement. Vaccine 2001;19:2440-2445.

22. Kaufman D. Recent and prospective mothers' attitudes and preferences regarding newborn genetic screening: a survey of 2,266 U.S. women. Paper presented at Advisory Committee on Heritable Disorders in Newborns and Children: 23rd meeting. Washington, DC, January 27, 2011.

23. Brase T. Newborn genetic screening: the new eugenics. Citizens Council on Health Care. Available at: http://www.cchfreedom.org/pdf/NBS_EUGENICS_ REPORT_Apr2009_FINAL.pdf. Accessed April 22, 2011.

24. Michigan Department of Community Health. Michigan BioTrust for Health, 2011. Available at: http://www.michigan.gov/mdch/0,1607,7-132-2942_ 4911_4916-209738-,00.html. Accessed April 22, 2011. 